\title{
FTIR study of acetylacetone, D2-acetylacetone and hexafluoroacetylacetone-water complexes in argon and nitrogen matrices
}

\author{
Justinas Čeponkus', \\ Rasa Platakyté丶 \\ Valdas Šablinskas ${ }^{1}$, \\ Alejandro Gutierrez Quintanilla ${ }^{2,3}$ \\ ${ }^{1}$ Institute of Chemical Physics, \\ Vilnius University, \\ Sauletekio Ave. 3, \\ 10257 Vilnius, Lithuania \\ ${ }^{2}$ Institut des Sciences Moléculaires d'Orsay, \\ Université Paris-Sud, \\ 91405 Orsay Cedex, France \\ ${ }^{3}$ Instituto Superior de Tecnologías \\ $y$ Ciencias Aplicadas, \\ 10600, La Habana, Cuba
}

\begin{abstract}
Association of acetylacetone molecules with water was studied by means of infrared absorption spectroscopy aided by matrix isolation technique. The spectra of acetylacetone-water mixtures isolated in low temperature argon and nitrogen matrices revealed additional spectral bands, not observed in the spectra of pure substances, thus confirming the formation of hydrogen bonded complexes. The precise assignment of the spectral bands was performed by varying the sample concentration, performing annealing experiments and DFT B3LYP $6-311++\mathrm{G}(3 \mathrm{df}, 3 \mathrm{pd})$ calculations. Positions of the associated water bands indicate a medium strength hydrogen bond comparable to the one observed in the water trimers. The effect of hydrogen bond formation is rather minimal for the acetylacetone molecule and our experiments confirm no significant influence on an internal hydrogen bond structure or dynamics in the acetylacetone molecule. Similar conclusions are valid in the case of the $\mathrm{D}_{2} \mathrm{O}$ D2-acetylacetone complex. Different situation is observed when $\mathrm{CH}_{3}$ groups in acetylacetone are replaced with $\mathrm{CF}_{3}$ groups. The calculated energy of the complex is twice as small. This is also confirmed by a very small bounded $\mathrm{OH}$ stretch shift. This observation confirms that the electronic structure of the molecular groups even relatively far away from the hydrogen bond accepting atom has a large influence on its possibility to form a hydrogen bond.
\end{abstract}

Keywords: infrared spectroscopy, matrix isolation, acetylacetone, water, hydrogen bond

\section{INTRODUCTION}

Hydrogen bonding plays a very important role in many aspects of physics, chemistry, and biology. This is especially true in the modern research in such fields as surface physics, biochemistry, and biophysics. Formation of hydrogen bonded complexes alters properties of the matter and might significantly influence processes occurring in chemical and biological systems [1-2]. Studies of water complexes with both organic and inorganic compounds are of particular interest.

Acetylacetone (AcAc) is a diketone molecule whose enolic form (Z-4-hydroxy-3-penten-2-one) is stabilized by an in-

\footnotetext{
*Corresponding author. Email: justinas.ceponkus@ff.vu.lt
}

ternal hydrogen bond and is therefore the most stable form. However, it coexists with the $\beta$-diketone tautomer (2,4-pentanedione is also called keto) in the gas phase or the liquid phase. The molecule presents an interesting case where its structure is determined by a strong intramolecular hydrogen bond [3-5]. Recent theoretical and experimental results indicate an existence of three large amplitude internal motions in this molecule, which results in a complicated dynamic structure of the molecule. Vibrational spectroscopy coupled together with low temperature experimental techniques provides excellent possibilities to study complicated molecules and molecular structures. AcAc has been extensively studied using the infrared absorption matrix isolation technique $5-$ 10]. Experiments performed in the parahydrogen matrices at temperatures below $4 \mathrm{~K}$ allowed one to establish the fact 
that large amplitude motions are preserved even when AcAc is isolated in a low temperature solid [1].

The influence of water on the structure and dynamics of an internal hydrogen bond in acetylacetone is an attractive problem as it is a very good model system for understanding complex processes in complicated macromolecules. In most molecules that are of biological interest there exist active molecular groups, such as $\mathrm{O}-\mathrm{H}, \mathrm{C}=\mathrm{O}$ and others, capable of forming internal and external hydrogen bonds.

Matrix isolation infrared spectroscopy is one of the most suitable experimental methods for studying such complicated molecular systems. The weak complexes are stabilized in the inert matrix host. Moreover, by changing the host to guest ratio one can observe the specific complex bands growing or disappearing depending on the sample concentration in the matrix [12].

In this work we present the study of an acetylacetone $(\mathrm{AcAc})$ and water complex by means of matrix isolation infrared absorption spectroscopy. Parallel to us, another group in the Department of Chemistry in the Tokyo University of Science did similar experiments with acetylacetone-water complexes and their deuterated analogues [13]. We expect our results for deuterated acetylacetone-deuterated water association to be less complicated and easier to interpret as we performed the experiments with deuterated substances, in contrary to Ref. 13 where partial deuteration was achieved by mixing normal acetylacetone with $\mathrm{D}_{2} \mathrm{O}$. The experiments described in Ref. 13 lead to a complicated situation where all possible mixed isotopologues of water and acetylacetone are observable in a single sample. In addition, we performed experiments with hexafluoroacetylacetone in order to further explore the effect of the terminal group atoms mass change influence on the properties of the intermolecular and intramolecular hydrogen bond. Spectral bands arising due to the formation of the complex are detected and assigned to the normal vibrations based on three techniques: mixture ratio variations, matrix annealing experiments and theoretically calculated spectra using the density functional theory (DFT) B3LYP. The influence of the mass and electronic structure on the process of hydrogen bond formation between acetylacetone and water molecules is explored by studying double deuterated acetylacetone (D2acetylacetone, $\mathrm{D} 2-\mathrm{AcAc}$ ) where $\mathrm{O}-\mathrm{H}$ and $\beta \mathrm{C}-\mathrm{H}$ hydrogens are changed to deuterons and hexafluoroacetylacetone (6F-AcAc), with $\mathrm{CH}_{3}$ groups changed to $\mathrm{CF}_{3}$ groups.

\section{METHODOLOGIES}

\section{Experimental}

Acetylacetone (99\%) and hexafluoroacetylacetone (99\%) from Sigma-Aldrich were degassed in the vacuum system and used without further purification. D2-acetylacetone was prepared using the technique described in [14]. Water was filtered and distilled using an EASYpure RoDi (Thermo Fisher Scientific) water purification system, and degassed by using a freeze pump thaw cycle. Nitrogen $(99.99 \%)$ and argon
(99.99\%) gases from Elme Messer Gaas were used without an additional treatment.

Sample-matrix gas mixtures were prepared in the glass vacuum system. Sample-matrix gas ratios were estimated by measuring the partial gas pressure in the vacuum system. A typical sample to the matrix gas ratio of 1 to 500 was used in most experiments. AcAc-water ratios were varied in a wide range in order to obtain spectra with different amounts (in comparison to monomers) and sizes (e.g. 1 water, 1 AcAc molecule or 2 water, $1 \mathrm{AcAc}$ ) of complexes. In a typical experiment approximately $20 \mathrm{mmol}$ of the gas mixture were deposited for 90 min onto a CsI window held at $9 \mathrm{~K}$ in a closed cycle He cryostat (Leybold-Heraeus RW2).

The IR spectra were recorded in the $500-4000 \mathrm{~cm}^{-1}$ range using a Bruker IFS 113 spectrometer at $1 \mathrm{~cm}^{-1}$ resolution. The background spectra and the sample spectra were measured under the same conditions, measuring and averaging 256 spectra. In order to follow complex formation in the matrix sample warming experiments were performed. The spectra were recorded at 9, 20, 25 and $30 \mathrm{~K}$ temperature. During the experiments where nitrogen gas was used, one spectrum was recorded at $35 \mathrm{~K}$ temperature as well.

\section{Calculations}

The density functional theory (DFT) at the B3LYP/6$311++\mathrm{G}(3 \mathrm{df}, 3 \mathrm{dp})$ [15] level was used to optimize the geometries and calculate harmonic frequencies of complexes consisting of one acetylacetone and one water molecule. All calculations were performed using the Gaussian 09 program package [16]. In a typical calculation the NoSymm keyword was used in order to ensure that the calculation program does not enforce an incorrect symmetry for the AcAc molecule.

\section{RESULTS AND DISCUSSION}

\section{Quantum chemistry calculations}

The structure of water and acetylacetone molecules allows several possible 1:1 complex geometries. There are three active centers of the AcAc molecule which are expected to be sites for interaction with the water molecule. Those are an oxygen atom from the $\mathrm{C}=\mathrm{O}$ group, an oxygen atom from the $\mathrm{C}-\mathrm{O}-\mathrm{H}$ group and a $\beta$-hydrogen atom in the $\mathrm{C}-\mathrm{H}$ group of acetylacetone. The performed calculations predict that all three mentioned complexes are indeed local minima on the potential energy surface. The optimized geometries and calculated energy differences are presented in Fig. 1. The most stable and thus most expected to be observed experimentally is the configuration where water bonds to the $\mathrm{C}=\mathrm{O}$ group of acetylacetone $(\mathrm{C}=\mathrm{O}$ side complex). The calculated binding energy for this structure is $23.6 \mathrm{~kJ} / \mathrm{mol}$. The next in energy is the structure where water bonds to the $\mathrm{O}-\mathrm{H}$ side with the calculated binding energy of $16.5 \mathrm{~kJ} / \mathrm{mol}$. This gives the energy difference of $7.1 \mathrm{~kJ} / \mathrm{mol}$ between two calculated structures. The least stable complex structure according to the calculations is the one where water bonds to the acetylacetone $\beta \mathrm{C}-\mathrm{H}$ group (see Fig. 11), the binding 


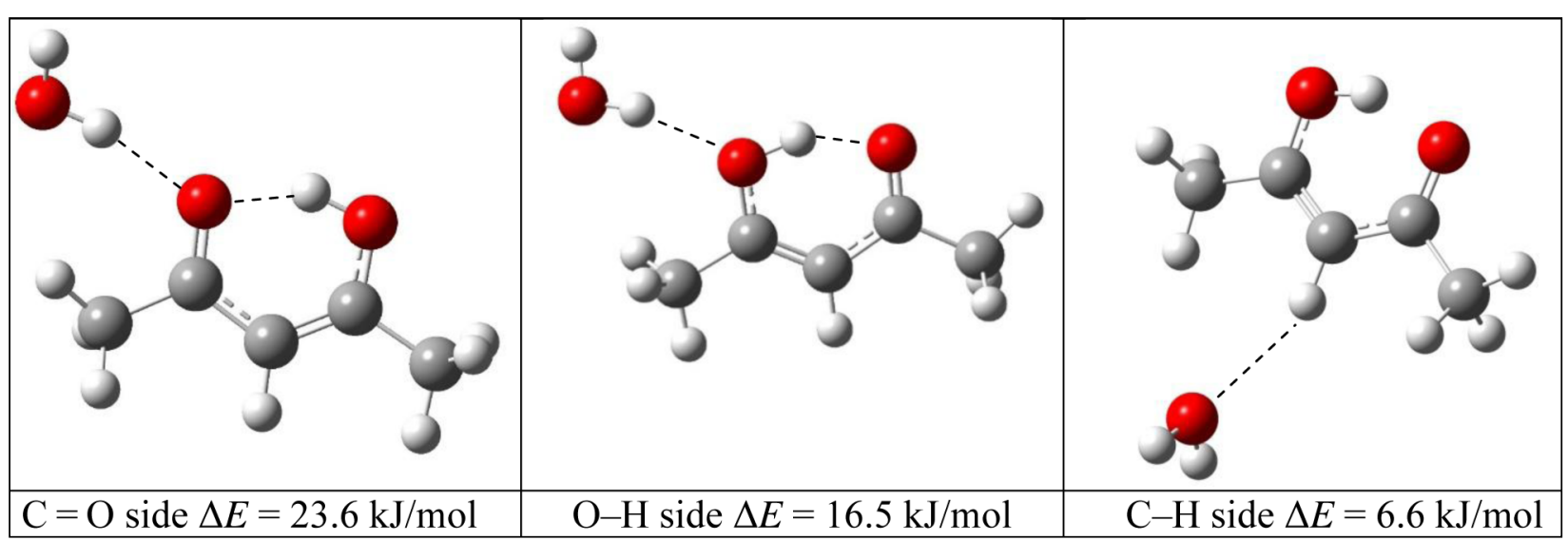

Fig. 1. The calculated structures of acetylacetone-water complexes and their binding energies

energy of this structure is only $6.6 \mathrm{~kJ} / \mathrm{mol}$ and the energy difference compared to the most stable $\mathrm{C}=\mathrm{O}$ side complex is $17 \mathrm{~kJ} / \mathrm{mol}$. The calculated energy differences between the structures allow us to estimate the possible abundances of these structures. Based on the Boltzmann distribution at room temperature the amount of the second in stability $\mathrm{O}-\mathrm{H}$ side structure could be in the order of 5\% (and the least stable $\beta \mathrm{C}-\mathrm{H}$ complex around $0.08 \%$ ). At this point one can disregard the least stable conformer from further consideration as the amount is much smaller than the expected detection limit of the experiment (roughly estimated at $1 \%$ ). The calculations of $\mathrm{D}_{2} \mathrm{O}$ D2-acetylacetone structural parameters and energies are, in fact, exactly the same as for the $\mathrm{H}_{2} \mathrm{O}$-acetylacetone complex and this is not surprising as the electronic energy of the system is not changed upon the deuteration. If the vibrational zero point energy is taken into account, the deuterated complex binding energy is estimated to be higher by $1.7 \mathrm{~kJ} / \mathrm{mol}$ than that of the hydrogenated one. In order to further investigate the influence of mass and electronic changes in acetylacetone on the forming of the hydrogen bonded complex with water we have studied hexafluoroacetylacetone where two $\mathrm{CH}_{3}$ groups are exchanged with $\mathrm{CF}_{3}$ groups (see Fig. 2). According to the calculations, hydrogen-fluorine exchange has a major influence on the structure and binding energy of the $\mathrm{H}_{2} \mathrm{O} \mathrm{F6-}$ AcAc complex. The most stable structure of this complex is different from AcAc water - the repulsion between electronegative oxygen in water and fluorine atoms in F6-AcAc increases the intermolecular distance. The hydrogen atom of the free $\mathrm{OH}$ group in the water molecule is turned towards the $\mathrm{CF}_{3}$ group, but is also rather far away and the attraction cannot compensate for the repulsion between oxygen and fluorine. The binding energy of the most stable structure is $11.5 \mathrm{~kJ} / \mathrm{mol}$ - much smaller than in the case of the AcAc-water complex.

\section{Experimental results}

Theoretical calculations allow us to expect that at least one type of a hydrogen bonded complex between AcAc and water should be detectable experimentally. The matrix isolation experimental technique makes it possible to stabilize weak com-

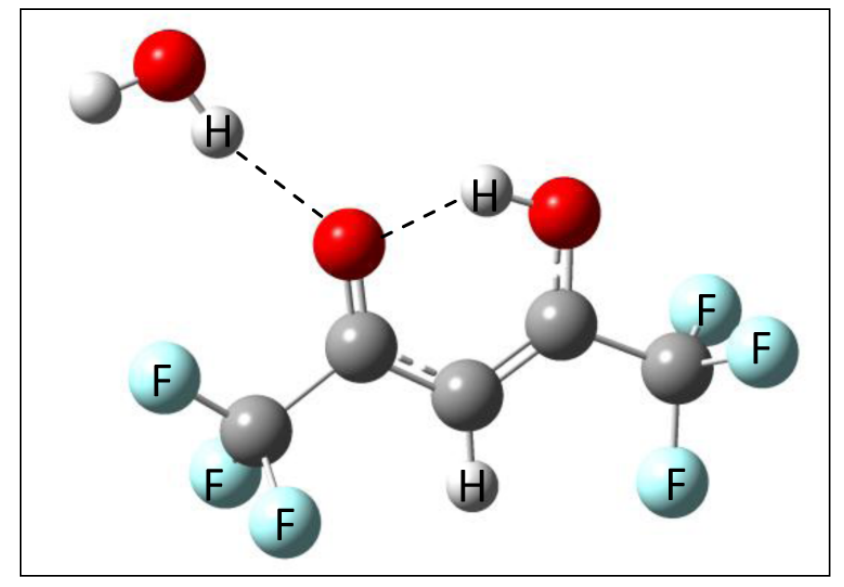

Fig. 2. The calculated structure of hexafluoroacetylacetone-water complex

plexes and prevent formation of larger structures which would hinder detection of such complexes. The overview spectra in the whole middle infrared region of acetylacetone isolated in the nitrogen matrix (1:500), water isolated in the nitrogen matrix (1:500) and the acetylacetone-water mixture isolated in the nitrogen matrix (1:1:500) are presented in Fig. 3. Only a brief overview of these spectra already allows us to identify additional spectral bands in the spectrum of AcAc-water mixtures that are not observed in the spectra of pure compounds. The presence of these bands indicates that at least one type of the complex is formed.

Overviewing the spectra together with the theoretically calculated spectra (see Table 1) allows us to identify the spectral regions where one can expect to see the most distinct spectral bands associated with AcAc-water complex formation. According to the calculations and the experimental spectrum the most obvious spectral changes are occurring in the spectral region between $3800-3300 \mathrm{~cm}^{-1}$. In this region the $\mathrm{O}-\mathrm{H}$ stretch vibration of water is expected to be observable. Figure 4 compares the spectra of pure water and AcAc-water mixtures isolated in the nitrogen matrix. One can also expect the AcAc $\mathrm{O}-\mathrm{H}$ stretch band somewhere in this region, but it is well 


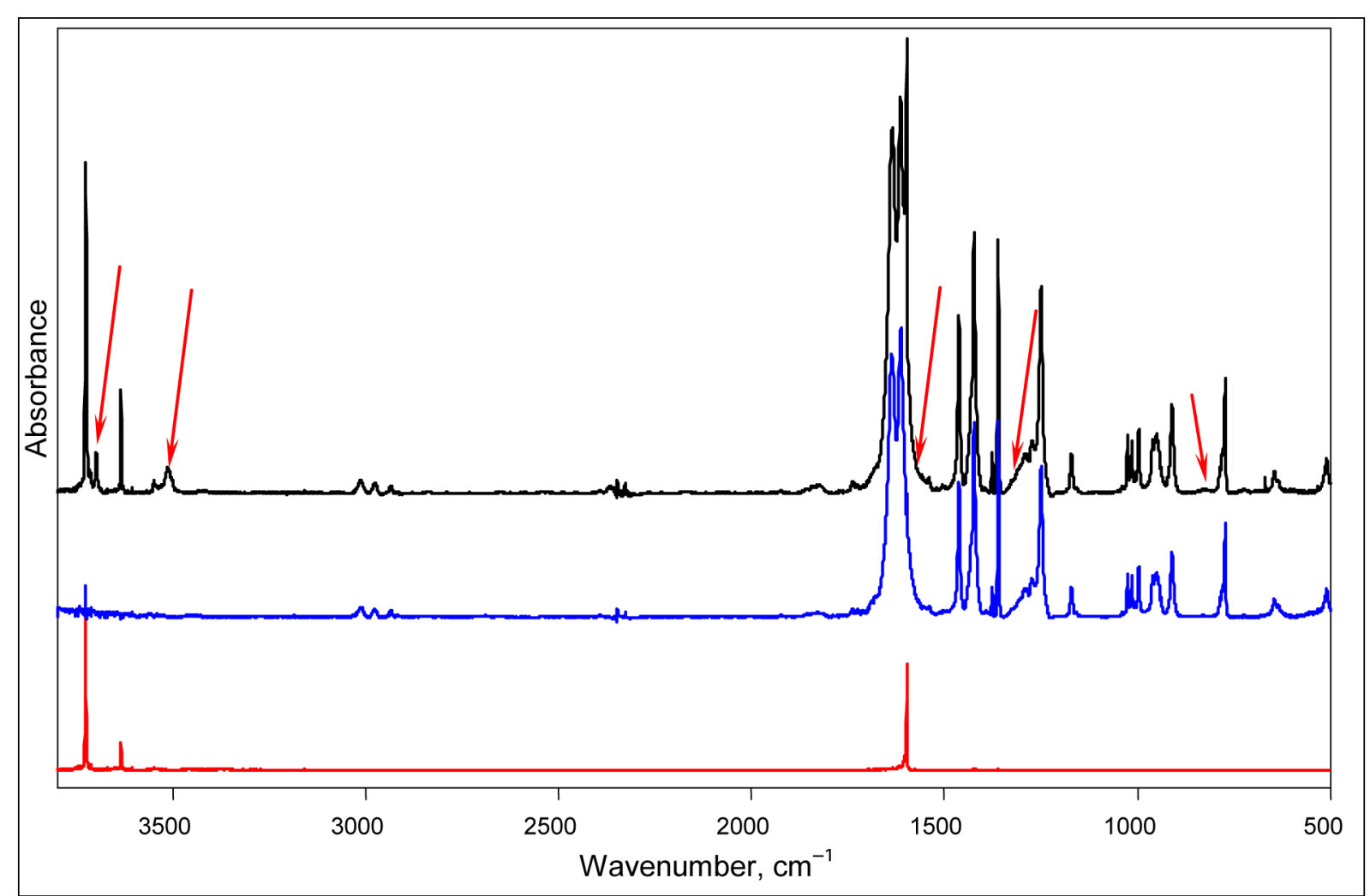

Fig. 3. The infrared absorption spectra of water (bottom), acetylacetone (middle) and acetylacetone-water mixture (top) isolated in the nitrogen matrix at $9 \mathrm{~K}$. Complex bands are denoted by arrows

Table 1 . The experimentally observed and calculated bands (in $\mathrm{cm}^{-1}$ ) of acetylacetone-water complex

\begin{tabular}{|c|c|c|c|c|c|c|c|c|}
\hline \multicolumn{4}{|c|}{ Experimental } & \multicolumn{4}{|c|}{ Calculations } & \multirow[b]{2}{*}{ Description } \\
\hline $\mathrm{AcAc}+\mathrm{H}_{2} \mathrm{O}(\mathrm{Ar})$ & $\mathrm{AcAc}+\mathrm{H}_{2} \mathrm{O}\left(\mathrm{N}_{2}\right)$ & $\operatorname{AcAc}(\mathrm{Ar})$ & $\operatorname{AcAc}\left(\mathrm{N}_{2}\right)$ & $\begin{array}{c}\mathrm{AcAC}+\mathrm{H}_{2} \mathrm{O} \\
\mathrm{C}=0 \text { side }\end{array}$ & $\begin{array}{c}\mathrm{AcAC}+\mathrm{H}_{2} \mathrm{O} \\
\mathrm{O}-\mathrm{H} \text { side }\end{array}$ & AcAc & Int. & \\
\hline \multicolumn{8}{|l|}{3776.7} & $\mathrm{H}_{2} \mathrm{O} v_{\text {as }}$ \\
\hline 3755.7 & \multicolumn{3}{|l|}{3726.7} & & & & & $\mathrm{H}_{2} \mathrm{O}$ vas \\
\hline \multicolumn{4}{|l|}{3711.5} & & & & & $\mathrm{H}_{2} \mathrm{O} v_{\text {as }}$ \\
\hline \multirow[t]{2}{*}{3705.9} & \multicolumn{3}{|l|}{3699.2} & 3885.2 & \multicolumn{2}{|l|}{3889.9} & 90 & $\mathrm{vOH}$ (free) $\mathrm{H}_{2} \mathrm{O}+\mathrm{AcAc}$ \\
\hline & \multicolumn{3}{|l|}{3634.1} & & & & & $\mathrm{H}_{2} \mathrm{O} v_{s}$ \\
\hline 3573.7 & \multicolumn{3}{|l|}{3550.7} & & & & & $\left(\mathrm{H}_{2} \mathrm{O}\right)$ dimer \\
\hline \multicolumn{4}{|l|}{3514.1} & & & & & $\left(\mathrm{H}_{2} \mathrm{O}\right)$ trimer \\
\hline 3512.1 & \multicolumn{3}{|l|}{3514.3} & 3640.8 & \multicolumn{2}{|l|}{3737.4} & 592 & vOH (bound) $\mathrm{H}_{2} \mathrm{O}+\mathrm{AcAc}$ \\
\hline \multirow[t]{2}{*}{3495.1} & & & & & & & & $\mathrm{vOH}$ (bound) $\mathrm{H}_{2} \mathrm{O}+\mathrm{AcAc}$ \\
\hline & & & & 3219.1 & 3215.1 & 3211.9 & 3 & $\mathrm{vCH}$ \\
\hline \multirow{2}{*}{3014.3} & \multirow{2}{*}{3014.0} & \multirow{2}{*}{3016.1} & \multirow{2}{*}{3013.6} & 3142.0 & 3144.6 & 3143.3 & 3 & $\mathrm{v}_{\mathrm{as}} \mathrm{CH}$ methyl- $\mathrm{C}=\mathrm{O}$ side \\
\hline & & & & 3141.3 & 3140.3 & 3137.9 & 8 & $\mathrm{~V}_{\mathrm{as}} \mathrm{CH}$ methyl-OH side \\
\hline \multirow{2}{*}{2979.0} & \multirow{2}{*}{2976.6} & \multirow{2}{*}{2979.3} & \multirow{2}{*}{2976.5} & 3096.3 & 3092.0 & 3090.6 & 10 & $\mathrm{v}_{\mathrm{as}} \mathrm{CH}$ methyl- $\mathrm{C}=\mathrm{O}$ side \\
\hline & & & & 3092.1 & 3088.9 & 3088.1 & 4 & $\mathrm{~V}_{\text {as }} \mathrm{CH}$ methyl-OH side \\
\hline & & & & 3067.9 & 2870.6 & 3005.2 & 405 & $\mathrm{vOH}(\mathrm{AcAc})$ \\
\hline \multirow{2}{*}{2932.8} & \multirow{2}{*}{2934.6} & \multirow{2}{*}{2931.7} & 20345 & 3039.6 & 3039.4 & 3038.7 & 1 & $\mathrm{v}_{\mathrm{s}} \mathrm{CH}$ methyl-OH side \\
\hline & & & & 3033.5 & 3035.0 & 3034.4 & 2 & $\mathrm{v}_{\mathrm{s}} \mathrm{CH}$ methyl- $\mathrm{C}=\mathrm{O}$ side \\
\hline & 1827.2 & & & & & & & \\
\hline 1711.8 & 1739.3 & 1712.1 & & & & & & \\
\hline
\end{tabular}




\begin{tabular}{|c|c|c|c|c|c|c|c|c|}
\hline \multicolumn{9}{|c|}{ Table 1. (continued) } \\
\hline \multicolumn{4}{|c|}{ Experimental } & \multicolumn{4}{|c|}{ Calculations } & \multirow[b]{2}{*}{ Description } \\
\hline $\mathrm{AcAc}+\mathrm{H}_{2} \mathrm{O}(\mathrm{Ar})$ & $\mathrm{AcAc}+\mathrm{H}_{2} \mathrm{O}\left(\mathrm{N}_{2}\right)$ & $\operatorname{AcAc}(\mathrm{Ar})$ & $\operatorname{AcAc}\left(\mathrm{N}_{2}\right)$ & $\begin{array}{l}\mathrm{AcAC}+\mathrm{H}_{2} \mathrm{O} \\
\mathrm{C}=0 \text { side }\end{array}$ & $\begin{array}{c}\mathrm{AcAc}+\mathrm{H}_{2} \mathrm{O} \\
\mathrm{O}-\mathrm{H} \text { side }\end{array}$ & AcAc & Int. & \\
\hline 1635.4 & 1636.0 & 1637.5 & 1636.5 & 1668.1 & 1678.9 & 1676.5 & 480 & $\mathrm{vC}=\mathrm{O}+\mathrm{vC}=\mathrm{C}-\mathrm{OH}+\delta \mathrm{OH}$ \\
\hline 1624.1 & 1598.7 & & & & & & & $\mathrm{vC}=\mathrm{O}+\mathrm{vC}=\mathrm{C}-\mathrm{OH}+\delta \mathrm{OH}$ \\
\hline 1617.3 & 1614.1 & 1616.5 & 1597.7 & 1624.7 & 1644.6 & 1644.9 & 284 & $\mathrm{vC}=\mathrm{O}+\mathrm{vC}=\mathrm{C}-\mathrm{OH}+\delta \mathrm{OH}(\mathrm{AcAc})+$ \\
\hline 1590.0 & & & 1613.8 & 1657.8 & 1654.2 & - & 7 & $\delta \mathrm{OH}\left(\mathrm{H}_{2} \mathrm{O}\right)$ bound to $\mathrm{AcAc}$ \\
\hline 1474.6 & 1464.6 & 1474.8 & 1463.3 & 1495.6 & 1488.7 & 1491.5 & 56 & $\begin{array}{c}\delta \mathrm{CH}_{\mathrm{ol} .}+\mathrm{vC}-\mathrm{C}=\mathrm{O}+\mathrm{vC}-\mathrm{OH}+\gamma \mathrm{CH} \\
\text { methyl (both) }\end{array}$ \\
\hline 1462.0 & & 1462.7 & & 1483.6 & 1476.8 & 1477.0 & 8 & $\begin{array}{c}\delta \mathrm{OH}(\mathrm{AcAc})+\gamma \mathrm{CH} \text { methyl- } \\
\mathrm{C}=\mathrm{O}+\gamma \mathrm{CH} \text { methyl-OH }\end{array}$ \\
\hline \multirow{2}{*}{1431.9} & & 1433.1 & & 1472.4 & 1475.7 & 1472.2 & 11 & $\begin{array}{c}\delta \mathrm{OH}(\mathrm{AcAc})+\gamma \mathrm{CH} \text { methyl- } \\
\mathrm{C}=\mathrm{O}+\gamma \mathrm{CH} \text { methyl-OH }+\delta \mathrm{CH}\end{array}$ \\
\hline & & & & 1472.2 & 1472.1 & 1471.5 & 9 & $\begin{array}{c}\delta \mathrm{OH}(\mathrm{AcAc})+\gamma \mathrm{CH} \text { methyl- } \\
\mathrm{C}=\mathrm{O}+\gamma \mathrm{CH} \text { methyl-OH }\end{array}$ \\
\hline 1422.8 & 1425.1 & 1423.7 & 1423.2 & 1457.6 & 1460.5 & 1459.8 & 124 & $\begin{array}{c}\delta \mathrm{OH}(\mathrm{AcAc})+\gamma \mathrm{CH} \text { methyl- } \\
\mathrm{C}=\mathrm{O}+\gamma \mathrm{CH} \text { methyl- } \mathrm{C}=\mathrm{O}-\mathrm{H}+\delta \mathrm{CH}\end{array}$ \\
\hline 1373.9 & 1376.7 & 1375.1 & 1377.0 & 1412.2 & 1416.0 & 1411.7 & 15 & $\delta_{s} \mathrm{CH}$ methyl- $\mathrm{C}=\mathrm{O}-\mathrm{H}$ \\
\hline 1369.1 & & 1369.7 & & 1399.4 & 1392.1 & 1391.6 & 41 & $\delta_{s} \mathrm{CH}$ methyl- $\mathrm{C}=\mathrm{O}$ \\
\hline \multirow[t]{3}{*}{1360.3} & 1361.4 & 1360.3 & 1361.2 & 1374.6 & 1361.6 & 1376.3 & 176 & $\delta O H(A c A c)+v C=C-O+v C=O$ \\
\hline & 1291.0 & & 1290.7 & & & & & \\
\hline & 1275.6 & & 1272.4 & & & & & \\
\hline 1251.2 & 1249.3 & 1251.1 & 1249.4 & 1273.5 & 1277.0 & 1270.8 & 130 & $\begin{array}{c}\delta \mathrm{OH}(\mathrm{AcAc})+\mathrm{V}_{\mathrm{s}} \mathrm{C}-\mathrm{C}-\mathrm{C}=\mathrm{C}-\mathrm{C} \text { ring } \\
\text { breath }\end{array}$ \\
\hline \multirow[t]{2}{*}{1173.9} & 1172.4 & 1174.3 & 1171.6 & 1199.6 & 1195.5 & 1195.0 & 13 & $\delta \mathrm{CH}$ \\
\hline & & 1170.2 & & 1063.6 & 1064.1 & 1063.4 & 1 & TCH methyl-OH side \\
\hline 1024.4 & 1025.0 & 1024.1 & 1025.7 & 1048.1 & 1048.2 & 1047.2 & 11 & $\mathrm{TCH}$ methyl $-\mathrm{C}=\mathrm{O}$ side \\
\hline 1012.7 & 1014.2 & 1012.6 & 1014.8 & 1036.8 & 1039.7 & 1034.8 & 11 & $\rho \mathrm{CH}_{3}$ methyl-OH side \\
\hline \multicolumn{9}{|l|}{1004.811} \\
\hline 995.8 & 995.4 & 1005.1 & 996.5 & 1020.6 & 1031.5 & 1010.3 & 18 & $\rho \mathrm{CH}_{3}$ (both) \\
\hline \multirow[t]{3}{*}{957.0} & 936.0 & 996.3 & 960.5 & 987.4 & 1009.4 & 1010.0 & 65 & $\mathrm{\gamma OH}(\mathrm{AcAc})$ \\
\hline & 949.7 & 956.8 & 949.1 & & & & & \\
\hline & 939.7 & 919.6 & 938.2 & 952.3 & 944.1 & 943.2 & 2 & $\rho \mathrm{CH}_{3}$ (both) $+v C-\mathrm{C}=\mathrm{O}$ \\
\hline \multirow[t]{3}{*}{920.8} & 920.1 & 910.3 & 910.3 & 926.3 & 917.3 & 918.2 & 30 & $\mathrm{vC}-\mathrm{CH}_{3}$ \\
\hline & 785.9 & & 786.3 & & & & & \\
\hline & 780.5 & & 779.0 & & & & & \\
\hline 769.4 & 773.1 & 766.3 & 772.9 & 799.9 & 799.4 & 794.0 & 31 & $\gamma \mathrm{CH}$ \\
\hline \multirow[t]{4}{*}{765.3} & 667.6 & & & & & & & \\
\hline & 662.3 & & 662.3 & & & & & \\
\hline & 644.8 & & 644.1 & 661.9 & 655.0 & 652.9 & 7 & $\rho \mathrm{CH}_{3}$ (both) \\
\hline & 635.4 & & 635.6 & 644.6 & 649.5 & 647.9 & 10 & $\rho \mathrm{CH}_{3}$ (both) $+\gamma \mathrm{OH}\left(\mathrm{H}_{2} \mathrm{O}\right)$ \\
\hline
\end{tabular}

$v$ is stretch vibration, $\delta$ is in-plane deformation vibration, $\gamma$ is out-of-plane deformation vibration, $\rho$ is rocking vibration, $\tau$ is twist vibration.

known that due to a strong intramolecular hydrogen bond in AcAc this band is much broadened and highly red shifted. Due to these conditions this band was never identified in the low temperature matrices [10-11]. Water bands are readily identified from pure water isolated in nitrogen spectra and previous works [17-19]. In the spectra of the AcAc-water mixture isolated in nitrogen (Fig. 4) two additional spectral bands at 3699 and $3514 \mathrm{~cm}^{-1}$ (see Table 1) are observed. Based on the calculations these bands are assigned to the free $\mathrm{O}-\mathrm{H}$ stretch and the bound $\mathrm{O}-\mathrm{H}$ stretch, respectively. The bound $\mathrm{O}-\mathrm{H}$ stretch 


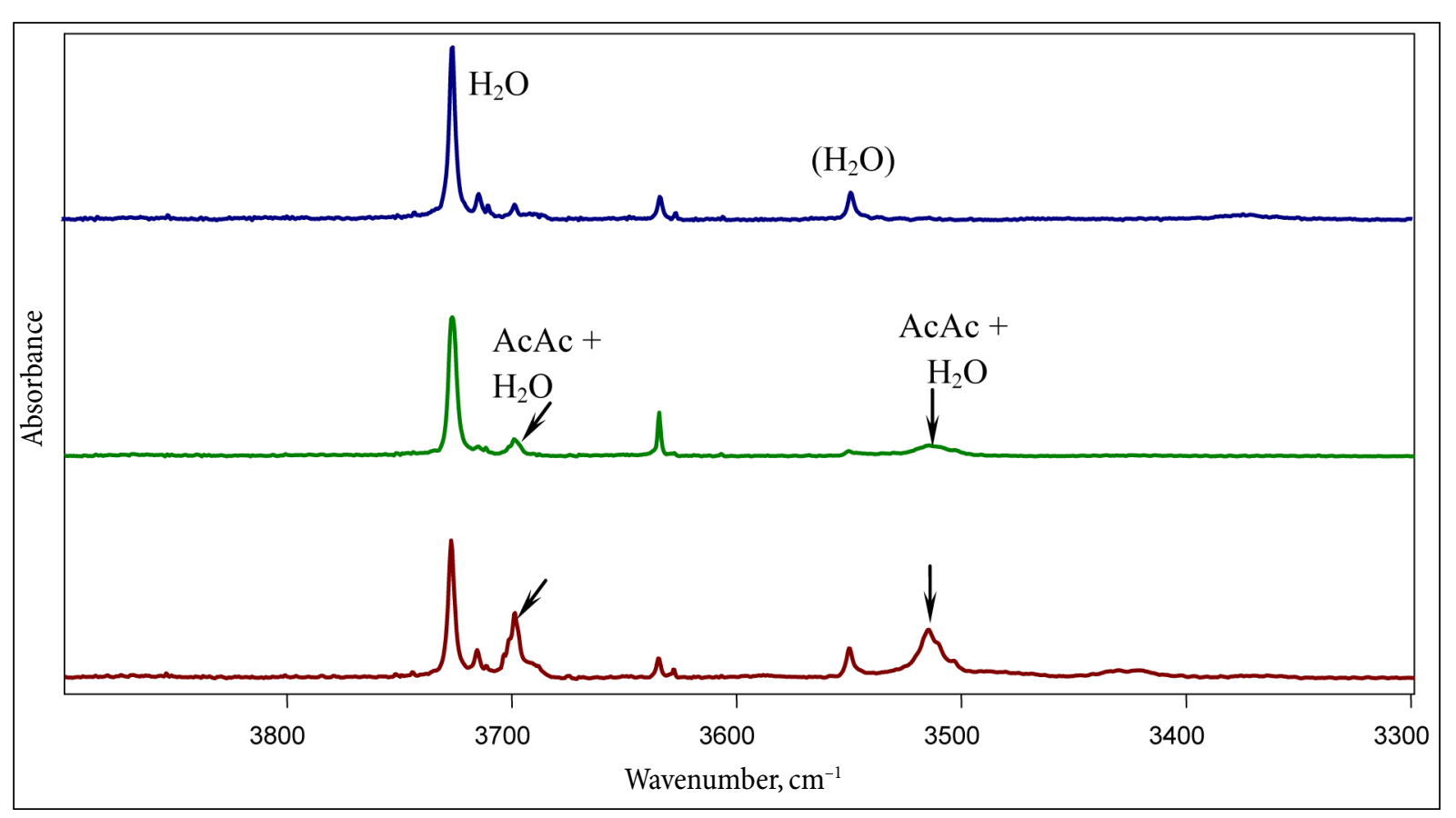

Fig. 4. The infrared absorption spectra of water isolated in nitrogen (1:500) (upper), acetylacetone-water mixture in nitrogen (1:1:500) (middle), acetylacetone-water mixture in nitrogen (1:2:500) (bottom). Complex bands are indicated by arrows

involves water hydrogen bonded to $\mathrm{AcAc}$ on the $\mathrm{C}=\mathrm{O}$ group side. The fact that only these bands are observed in the spectra suggests that in nitrogen only one type of the AcAc-water complex is observable. It is well known that the nitrogen matrix is a quite rigid molecular solid and most of molecular dynamics are blocked in this matrix, for example, water monomer rotates in argon matrices, but the rotation is stopped in nitrogen [20]. As a consequence, we see fewer peaks in the nitrogen matrix spectra thus making it easier to analyse.

In order to better explore possibilities to detect another type of the AcAc-water complex we have performed studies in argon matrices as well. We also compared these results to the ones produced by the group in Tokyo University and found that they are extremely similar [13]. The $\mathrm{O}-\mathrm{H}$ stretch region of pure water and the AcAc-water mixture isolated in argon matrices, together with the DFT calculated spectra of two possible AcAc-water complexes, are presented in Fig. 5. The bands we see in the pure water spectrum in the $3800-3700 \mathrm{~cm}^{-1}$ region (Fig. 5) can easily be assigned to water monomers. In a similar fashion, we can state that the band at $3573 \mathrm{~cm}^{-1}$ is the result of water dimer formation. We see that its intensity grows with increasing the water concentration and the sample temperature. In the spectra of the AcAc-water mixture isolated in argon we observe three additional spectral bands besides those of pure water. We can attribute the band at $3705.9 \mathrm{~cm}^{-1}$ (see Fig. 5 and Table 1) to the free $\mathrm{O}-\mathrm{H}$ stretch of water bound to acetylacetone, based on the calculations and annealing experiments. In this region two more bands are observable at 3512 and $3495 \mathrm{~cm}^{-1}$. These bands follow the same dynamics during the sample warming up from 9 to $30 \mathrm{~K}$. They grow in intensity exactly at the same rate. The same happens when the water concentration is increased in the mixture. These dynamics suggest that these two bands belong to the same molecular species. Moreover, the difference between these bands in the experimental spectrum equals to $15 \mathrm{~cm}^{-1}$ while the calculated separation between two different theoretically predicted structures is $100 \mathrm{~cm}^{-1}$. One more argument against the second structure observation is the calculated energy difference between two structures. The Boltzmann distribution allows us to expect the 1:20 ratio between two structures at room temperature. In the experimental spectra we observe almost 1:1 ratio of these two bands. All these experimental observations allow us to conclude that both of these bands are associated with the same $\mathrm{C}=\mathrm{O}$ side AcAc-water hydrogen bonded complex. The presence of these two bands could be explained by two hypotheses: the matrix cage effect or coupling with the internal motions of the AcAc molecule.

In order to try to clarify this effect, experiments with $\mathrm{D}_{2} \mathrm{O}$ and D2-acetylacetone were performed. Similar experiments carried out by the Tokyo group used a mixture of normal and deuterated water [13]. During our experiments, we tried to obtain $100 \% \mathrm{D} 2$-acetylacetone to make the analysis both easier and more accurate. Deuteration does not change an electronic structure of the system and the strength of the hydrogen bond is mainly determined by the change of the zero point vibrational energy. Mass increase from hydrogen to deuterium results in the change of vibrational frequencies involving $\mathrm{H} / \mathrm{D}$ atom vibration and thus the overall change of zero point vibrational energy. The $\mathrm{O}-\mathrm{D}$ stretch region of $\mathrm{D}_{2} \mathrm{O}$ and $\mathrm{D} 2$ acetylacetone isolated in the argon matrix is presented in Fig. 6 , and the complete assignment of vibrational bands is summarized in Table 2. From the experiments using 


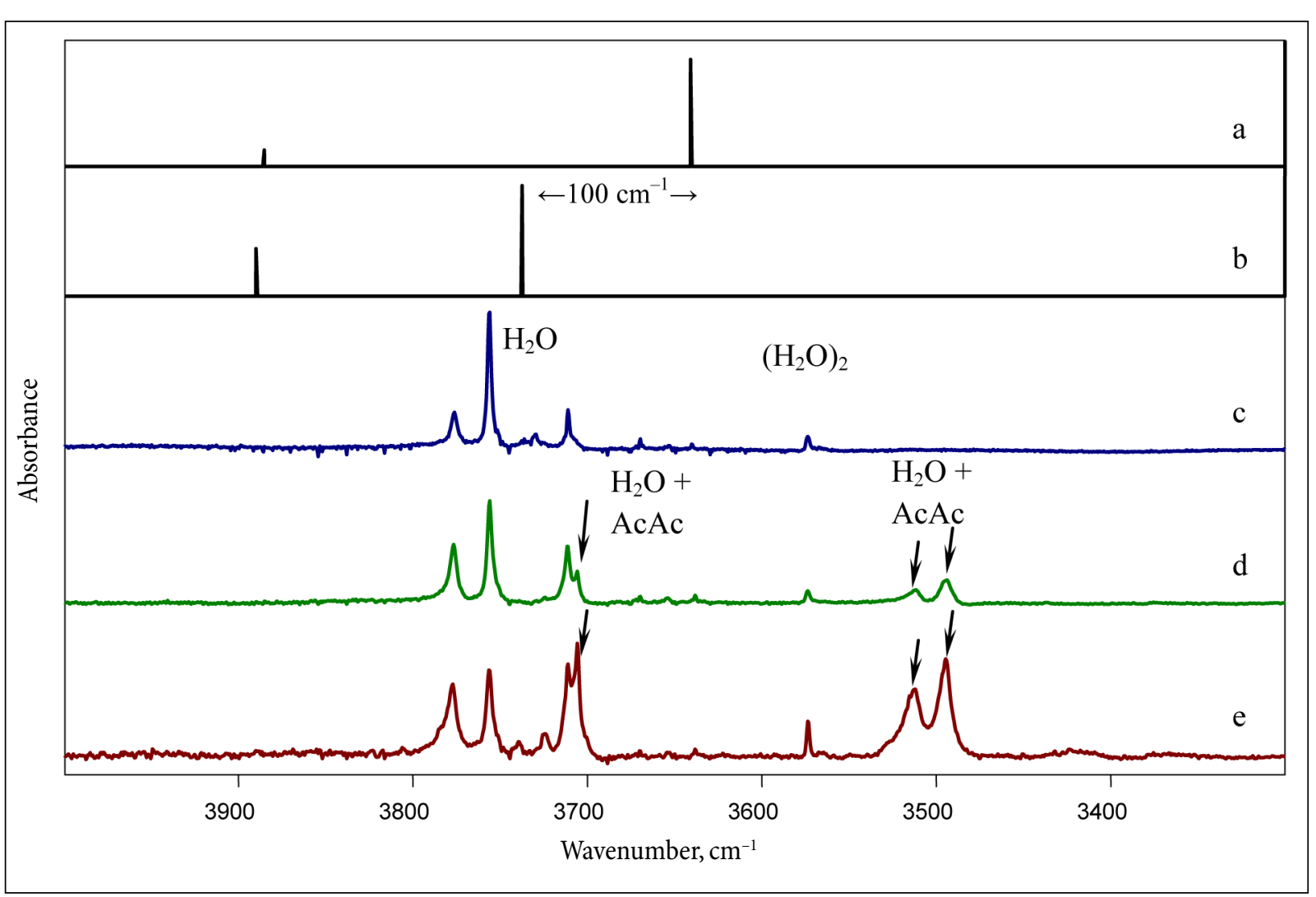

Fig. 5. (a) The calculated spectra of acetylacetone-water $\mathrm{C}=0$ side complex (most stabile); (b) the calculated spectra of acetylacetone-water $0-\mathrm{H}$ side complex; (c) the infrared absorption spectrum of water in argon (1:500) at $9 \mathrm{~K}$ temperature; (d) the infrared absorption spectrum of acetylacetone-water mixture in argon (1:1:500) at $9 \mathrm{~K}$; (e) the infrared absorption spectrum of acetylacetone-water mixture in argon (1:1:500) at $30 \mathrm{~K}$. Arrows denote complex bands

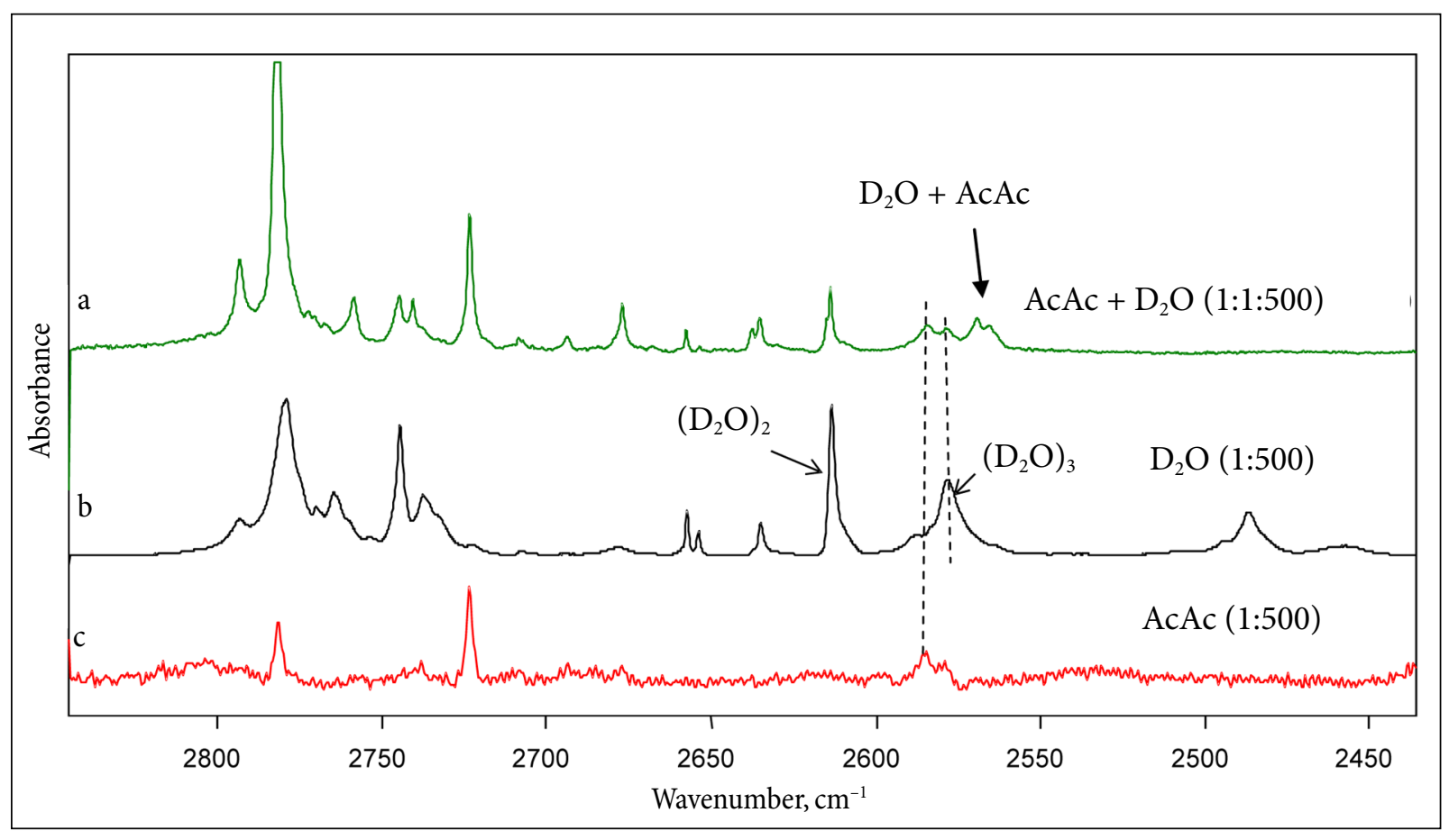

Fig. 6. (a) The infrared absorption spectrum of $D_{2} 0 \mathrm{D} 2$-acetylacetone mixture in argon (1:500) at $9 \mathrm{~K}$ temperature; (b) the infrared absorption spectrum of D2-acetylacetone-water mixture in argon (1:1:500) at $9 \mathrm{~K}$; (e) the infrared absorption spectrum of acetylacetone-water mixture in argon (1:1:500) at $30 \mathrm{~K}$. Arrows denote complex bands 
Table 2. The experimentally observed and calculated bands (in $\mathrm{cm}^{-1}$ ) of D2-acetylacetone-water complex

\begin{tabular}{|c|c|c|c|c|c|c|}
\hline \multicolumn{2}{|c|}{ Experimental } & \multicolumn{4}{|c|}{ Calculations } & \multirow{3}{*}{ Description } \\
\hline $\mathrm{D} 2 \mathrm{AcAc}+\mathrm{H}_{2} \mathrm{O}(\mathrm{Ar})$ & d2AcAc (Ar) & \multicolumn{2}{|c|}{$\mathrm{D} 2-\mathrm{AcAC}+\mathrm{H}_{2} \mathrm{O}$} & \multicolumn{2}{|c|}{ D2-ACAC } & \\
\hline Wavenumber & Wavenumber & Wavenumber & Int. & Wavenumber & Int. & \\
\hline & \multirow{2}{*}{3016.2} & 3141.8 & 1 & 3143.3 & 9 & $\mathrm{~V}_{\text {as }} \mathrm{CH}$ methyl $-\mathrm{C}=\mathrm{O}$ side \\
\hline & & 3141.2 & 8 & 3137.9 & 9 & $v_{\text {as }} \mathrm{CH}$ methyl-OD side \\
\hline & \multirow{2}{*}{2978.3} & 3096.4 & 9 & 3090.6 & 5 & $\mathrm{v}_{\mathrm{as}} \mathrm{CH}$ methyl- $\mathrm{C}=\mathrm{O}$ side \\
\hline & & 3092.0 & 4 & 3088.1 & 7 & $\mathrm{v}_{\mathrm{as}} \mathrm{CH}$ methyl-OD side \\
\hline & \multirow{2}{*}{2933.4} & 3039.8 & 6 & 3038.6 & 8 & $\mathrm{v}_{\mathrm{s}} \mathrm{CH}$ methyl-OD side \\
\hline & & 3033.7 & 3 & 3034.2 & 3 & $\mathrm{v}_{\mathrm{s}} \mathrm{CH}$ methyl $-\mathrm{C}=\mathrm{O}$ side \\
\hline 2740.6 & & 2835.2 & 83 & & & vOD (free) $D_{2} \mathrm{O}+\mathrm{AcAc}$ \\
\hline \multirow[t]{3}{*}{2569.1} & & 2638.2 & 276 & & & vOD (bound) $D_{2} O+A c A c$ \\
\hline & & 2379.1 & 1 & 2373.9 & 1 & $v C D$ \\
\hline & & 2243.2 & 281 & 2199.8 & 259 & $\operatorname{vOD}(\mathrm{AcAc})$ \\
\hline 1621.9 & 1632.4 & 1647.4 & 270 & 1662.8 & 263 & $v C=O+v C=C-O D$ \\
\hline 1534.4 & 1535.4 & 1551.2 & 482 & 1560.0 & 374 & $v C=O+v C=C-O D+\delta O D(A c A c)$ \\
\hline 1443.4 & 1443.4 & 1486.5 & 14 & 1477.0 & 13 & $\gamma \mathrm{CH}$ methyl $-\mathrm{C}=\mathrm{O}+\gamma \mathrm{CH}$ methyl-OH \\
\hline \multirow{2}{*}{1437.2} & \multirow{2}{*}{1437.2} & 1475.3 & 76 & 1475.8 & 79 & $\gamma \mathrm{CH}$ methyl $-\mathrm{C}=\mathrm{O}+\gamma \mathrm{CH}$ methyl-OH \\
\hline & & 1472.1 & 8 & 1472.2 & 9 & $\gamma \mathrm{CH}$ methyl-OH \\
\hline 1426.9 & 1425.6 & 1462.8 & 58 & 1464.7 & 39 & $\gamma \mathrm{CH}$ methyl $-\mathrm{C}=\mathrm{O}$ \\
\hline 1413.9 & 1413.9 & & & & & \\
\hline \multicolumn{7}{|l|}{1399.8} \\
\hline 1372.8 & 1372.8 & 1418.0 & 26 & 1418.2 & 29 & ${ }_{{ }_{s}} \mathrm{CH}$ methyl-OH \\
\hline \multirow{2}{*}{$1352.0^{*}$} & 1358.5 & 1405.7 & 11 & 1403.3 & 12 & $\mathrm{Y}_{\mathrm{s}} \mathrm{CH}$ methyl- $\mathrm{C}=\mathrm{O}$ \\
\hline & 1352.0 & 1391.8 & 45 & 1385.0 & 53 & $\gamma \mathrm{CH}_{3}$ (both) \\
\hline 1277.4 & 1277.4 & 1312.2 & 152 & 1303.1 & 126 & $\mathrm{vC}-\mathrm{C}+\rho \mathrm{CH}_{3}$ (both) \\
\hline \multicolumn{2}{|l|}{1195.2} & \multirow{3}{*}{1207.7} & & & & \\
\hline 1188.6 & & & 26 & & & $\delta \mathrm{OD}\left(\mathrm{D}_{2} \mathrm{O}\right)$ \\
\hline \multicolumn{6}{|l|}{1175.1} & \\
\hline 1086.9 & 1086.9 & 1117.0 & 44 & 1119.8 & 52 & $\delta O D(A c A c)+\rho \mathrm{CH}_{3}(\mathrm{CO})$ \\
\hline 1038.2 & 1038.2 & 1062.5 & 2 & 1062.2 & 1 & $\mathrm{TCH}_{3}(\mathrm{OH})$ \\
\hline \multirow{3}{*}{1026.4} & 1028.3 & 1048.7 & 28 & 1046.97 & 10 & $\tau \mathrm{TCH}_{3}(\mathrm{CO})+\rho \mathrm{CH}_{3}(\mathrm{OH})+\delta \mathrm{OD}(\mathrm{AcAc})$ \\
\hline & 1024.6 & 1047.3 & 17 & 1046.95 & 30 & $\mathrm{TCH}_{3}$ (both) \\
\hline & & & & & & $\rho \mathrm{CH}_{3}$ methyl-OH side \\
\hline $992.8^{*}$ & 992.8 & 1017.1 & 10 & 1009.4 & 10 & $\rho \mathrm{CH}_{3}$ (both) \\
\hline $937.8^{*}$ & 937.8 & 953.1 & 24 & 945.9 & 25 & $\rho \mathrm{CH}_{3}$ (both) $+\delta C D$ \\
\hline \multirow[t]{2}{*}{875.0} & 875.0 & 898.5 & 9 & 891.5 & 16 & $\rho \mathrm{CH}_{3}$ (both) $+\delta O D$ \\
\hline & $770.4^{*}$ & 853.3 & 0.1 & 847.5 & 1 & $\delta C D$ \\
\hline 718.6 & 718.6 & 7207 & 20 & 7500 & 20 & תח \\
\hline \multirow[t]{3}{*}{708.1} & 708.1 & 150.1 & Jo & 150.9 & 30 & $\gamma \in D$ \\
\hline & & 663.2 & 3 & 652.9 & 7 & $\mathrm{TCH}_{3}$ (both) $+\gamma \mathrm{OD}$ \\
\hline & & 641.5 & 11 & 647.9 & 10 & $\rho \mathrm{CH}_{3}(\mathrm{CO})$ \\
\hline
\end{tabular}


different concentrations of $\mathrm{D}_{2} \mathrm{O}$ and $\mathrm{D} 2$-AcAc we were able to identify two spectral bands associated with the bound $\mathrm{O}-\mathrm{D}$ stretch of $\mathrm{D}_{2} \mathrm{O}$ bonded to D2-AcAc. The separation between this doublet is smaller than in the normal water case - only $5 \mathrm{~cm}^{-1}$ while it is $12 \mathrm{~cm}^{-1}$ in normal water. The doublet separation change from hydrogen to deuterium is most likely associated with the matrix cage effect, as heavier deuterium atom vibration is probably less perturbed by surrounding argon atoms. The complex band is red shifted by $5 \mathrm{~cm}^{-1}$ from the $\mathrm{D}_{2} \mathrm{O}$ trimer band just like it was in the case of normal water. This indicates the same hydrogen bond strength change upon deuteration in the acetylacetone-water complex as it is observed in the water trimer. The spectral shift of the water $\mathrm{O}-\mathrm{H}$ stretch from the monomer (from the most intense monomer antisymmetric rovibrational band) to the acetylacetone-complex is $250 \mathrm{~cm}^{-1}$ in the hydrogenated complex and $220 \mathrm{~cm}^{-1}$ in the deuterated complex. A smaller shift in the deuterated system exhibits a weaker hydrogen bond. This effect is called the negative Ubbelohde effect and is in agreement with theoretical predictions for weakly bounded hydrogen bond complexes involving water [21]. A similar effect upon deuteration is also observed for the water trimer [18-19]. It is interesting to note that this experimental observation contradicts theoretical predictions at the DFT B3LYP $(6-311++\mathrm{G}(3 \mathrm{df}, 3 \mathrm{pd}))$ level where a deuterated form pre- dicted to be slightly stronger, but confirms Car-Parrinello molecular dynamics studies [21] where water involving hydrogen bond complexes is expected to have a slightly weaker hydrogen bond upon deuteration.

The infrared absorption region between $1800-600 \mathrm{~cm}^{-1}$ is associated mainly with acetylacetone vibrations. Water has some spectral bands associated with $\mathrm{H}-\mathrm{O}-\mathrm{H}$ bending vibrations between $1650-1550 \mathrm{~cm}^{-1}$. In the spectra of the AcAc-water mixture isolated in argon these bending vibrations heavily overlap with the broad bands of acetylacetone $\mathrm{C}=\mathrm{O}$ and $\mathrm{C}=\mathrm{C}$ stretching vibrations. Despite the complicated structure of the bands we were able to identify the $\mathrm{H}-\mathrm{O}-\mathrm{H}$ bending vibration band of water bound to AcAc at $1590 \mathrm{~cm}^{-1}$ (see Table 1 and Fig. D). It is much more difficult to observe any effect of the $\mathrm{AcAc}$-water bond on the $\mathrm{C}=\mathrm{O}$ and $\mathrm{C}=\mathrm{C}$ stretch modes of acetylacetone. This observation is rather different from the typical cases of hydrogen bonding between carbonyl groups of a molecule with water. Classical examples of such interactions are water-carboxylic acid or water-ethanol hydrogen bonded complexes [22-23]. In carboxylic acids the $\mathrm{C}=\mathrm{O}$ band is red shifted by $\mathrm{ca} .40 \mathrm{~cm}^{-1}$ from the monomer to the complex with water and is the most sensitive mode of carboxylic acids to the hydrogen bond formation. However, the $\mathrm{C}=\mathrm{O}$ band in acetylacetone is heavily coupled with the $\mathrm{C}=\mathrm{C}$ band and other ring vibrations. The combined width of overlapping $\mathrm{C}=\mathrm{O}$ and $\mathrm{C}=\mathrm{C}$ bands

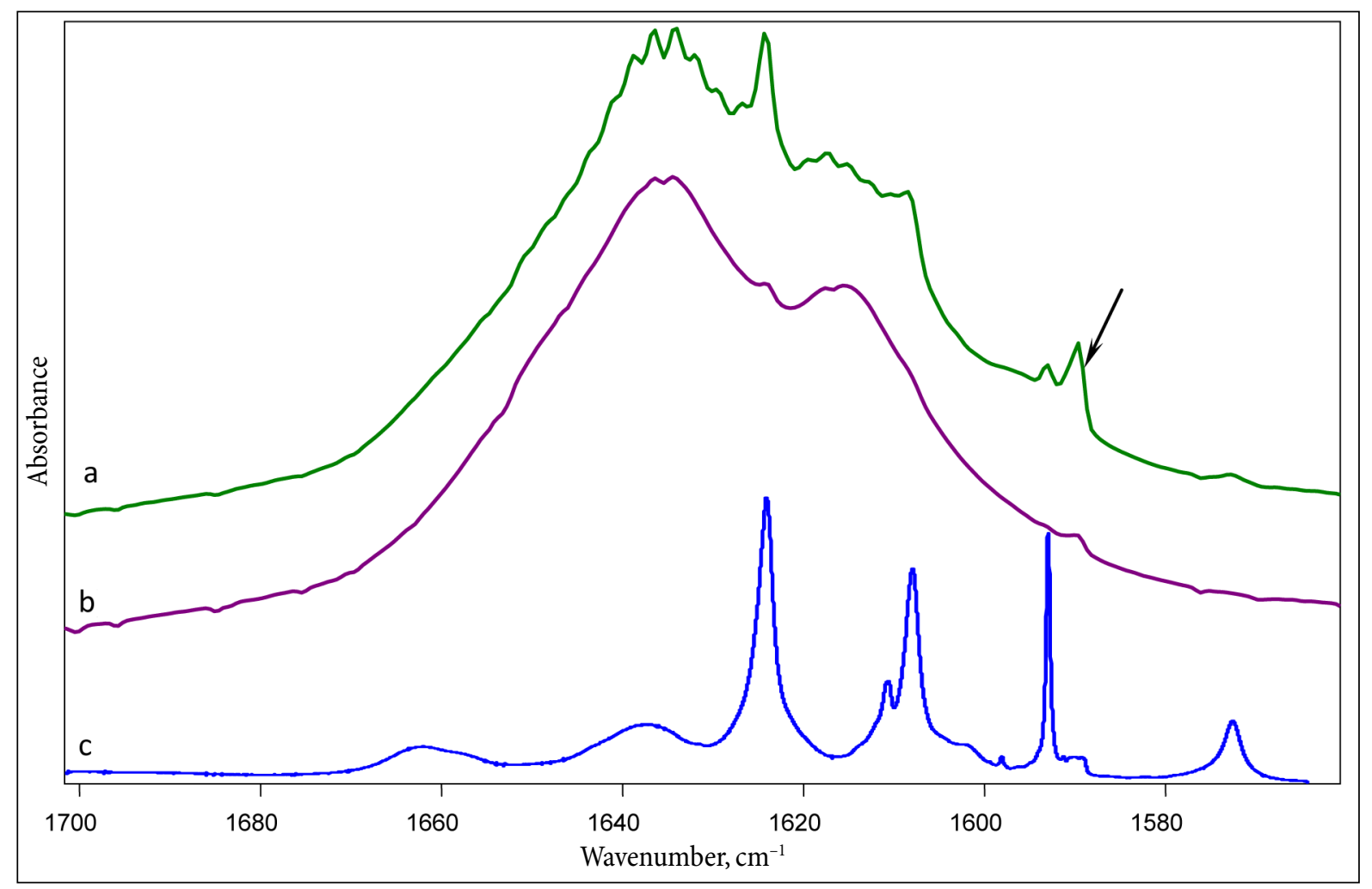

Fig. 7. (a) The infrared absorption spectrum of water-acetylacetone mixture in argon (1:1:1500) at $9 \mathrm{~K}$ temperature; (b) the infrared absorption spectrum of acetylacetone in argon (1:500) at $9 \mathrm{~K}$; (c) the infrared absorption spectrum of water in argon (1:200) at $9 \mathrm{~K}$. The arrow denotes $\delta($ bound $\mathrm{H}-0-\mathrm{H})$ of water hydrogen bonded to acetylacetone 
in acetylacetone is more than $100 \mathrm{~cm}^{-1}$, which could mask the red shifts of the $\mathrm{C}=\mathrm{O}$ band of acetylacetone bonded to water. A close look at the pure AcAc band and the AcAcwater mixture band in the region between $1700-1540 \mathrm{~cm}^{-1}$ reveals some additional broadening of the combined $\mathrm{C}=\mathrm{O}$ and $\mathrm{C}=\mathrm{C}$ band on the red side of spectra in the samples with added water. This, in fact, could be an indication of a slight disturbance of the $\mathrm{C}=\mathrm{O}$ band of acetylacetone upon bonding with water. A more clear red shift of the $\mathrm{C}=\mathrm{O}$ band is observed in the $\mathrm{D}_{2} \mathrm{O}$ D2-AcAc complex (Fig. 8). In this case $\mathrm{C}=\mathrm{O}$ and $\mathrm{C}=\mathrm{C}$ bands are much less coupled and one can clearly see an appearing shoulder on the $\mathrm{C}=\mathrm{O}$ band for the samples with an additional amount of $\mathrm{D}_{2} \mathrm{O}$. The red shift of the observed band from the monomer to AcAc bonded to $\mathrm{D}_{2} \mathrm{O}$ is $10 \mathrm{~cm}^{-1}$. This is still much smaller than expected for a medium strength hydrogen bond system which was concluded from the shifts of bound $\mathrm{O}-\mathrm{H}$ and $\mathrm{O}-\mathrm{D}$ stretches of water. This allows us to conclude that the internal hydrogen bond in AcAc highly reduces the external influence of the bonded water on the vibrations of the bound acetylacetone molecule.

Two additional spectral regions are expected to be sensitive to the formation of an external hydrogen bond in acetylacetone: the region around $1360 \mathrm{~cm}^{-1}$ where in-plane deformation vibrations of the $\mathrm{O}-\mathrm{H}$ group (see Table 1) are expected to be observable and the region between 1050 and $900 \mathrm{~cm}^{-1}$ where out-of-plane $\mathrm{O}-\mathrm{H}$ deformation vibrations are expected to contribute to infrared absorption. The spec- tral band at $1360 \mathrm{~cm}^{-1}$ is very broad both in argon and nitrogen matrices. This is not surprising as this motion highly delocalizes the $\mathrm{O}-\mathrm{H}$ proton in the AcAc molecule. We were unable to see any definitive change of this band upon complex formation between water and AcAc. This fact allows us to assume that the external hydrogen bond with water has only a very minor influence on the strength and dynamics of the internal hydrogen bond in the AcAc molecule.

In the $1050-900 \mathrm{~cm}^{-1}$ region, there are several AcAc vibrations which could be expected to be sensitive to the formation of a hydrogen bond with water (Table 1 and Fig. 9). As it can be seen from the data there is a slight shift of the $\mathrm{CH}_{3}$ rocking and twisting bands of $\mathrm{AcAc}$ in the $\mathrm{C}=\mathrm{O}$ group side. These shifts are observed both in the calculations and experimental spectra of AcAc water mixtures isolated in the nitrogen matrix. Even larger shifts are observed for $\mathrm{O}-\mathrm{H}$ out-of-plane deformation vibrations, calculations predict a $23 \mathrm{~cm}^{-1}$ red shift upon hydrogen bond formation (see Table 1) and experimentally in the nitrogen matrix we observe a $24 \mathrm{~cm}^{-1}$ red shift $\left(960 \mathrm{~cm}^{-1}\right.$ pure AcAc and $936 \mathrm{~cm}^{-1}$ AcAc-water complex). We also can observe a slight blue shift for the band associated with $\mathrm{C}-\mathrm{CH}_{3}$ stretch vibration: theory predicts a $8 \mathrm{~cm}^{-1}$ blue shift for the complex formation and experimentally we observe a band at $910 \mathrm{~cm}^{-1}$ for the pure AcAc and a broad shoulder at approximately $920 \mathrm{~cm}^{-1}$ for the AcAc-water mixture. The analysis of the argon data is much more complicated. The bands are much broader than in nitrogen and that makes it harder

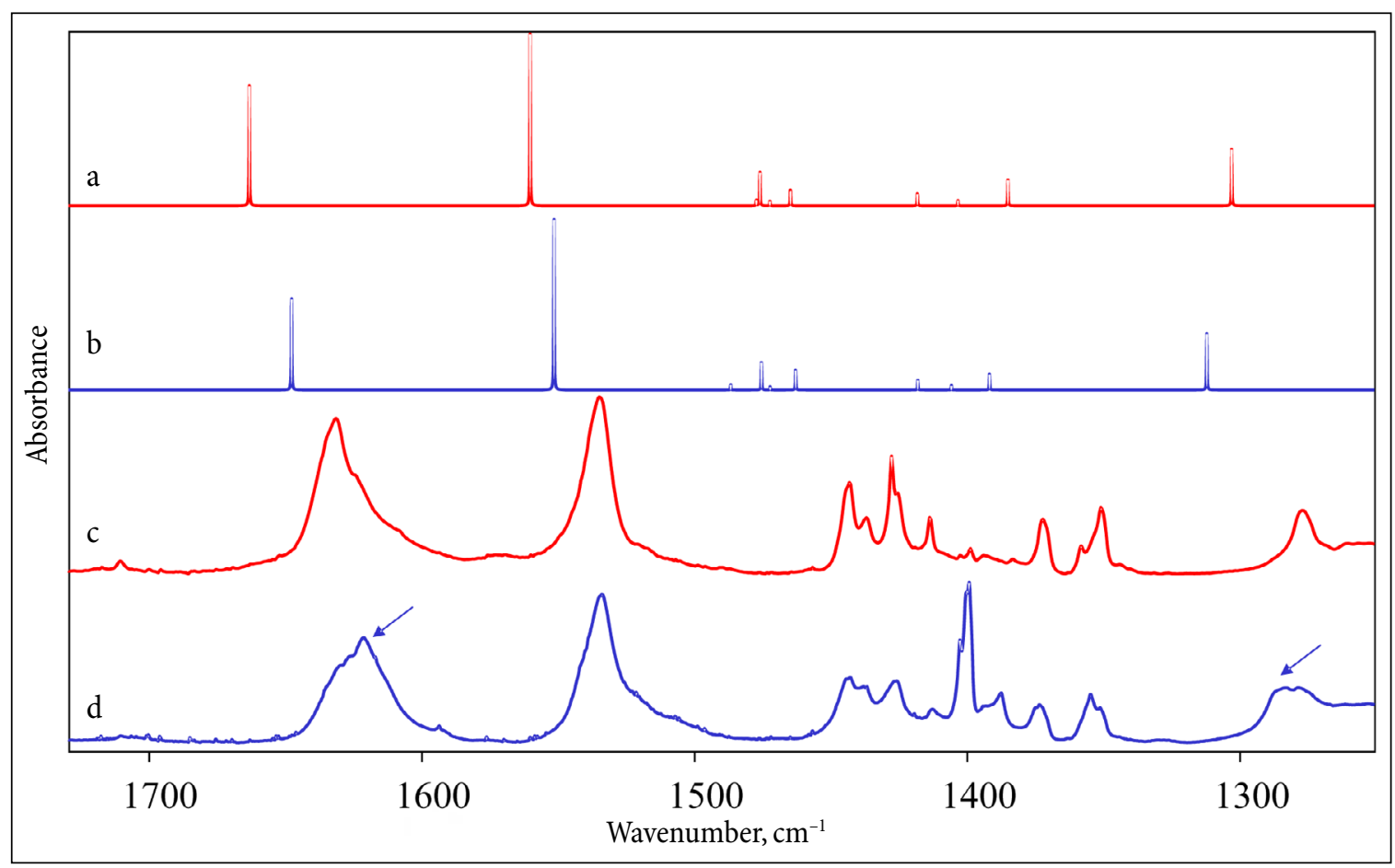

Fig. 8. (a) The calculated spectrum of $D 2$-acetylacetone; (b) the calculated spectra of $D 2$-acetylacetone $D_{2} O$ complex; (c) the infrared absorption spectrum of $\mathrm{D} 2$-acetylacetone in argon (1:500) at $9 \mathrm{~K}$ temperature; (d) the infrared absorption spectrum of $\mathrm{D} 2$-acetylacetone- $\mathrm{D}_{2} 0$ mixture in argon (1:1:500) at $9 \mathrm{~K}$. Arrows denote bands attributed to the $\mathrm{D} 2$-acetylacetone bound to $\mathrm{D}_{2} 0$ 


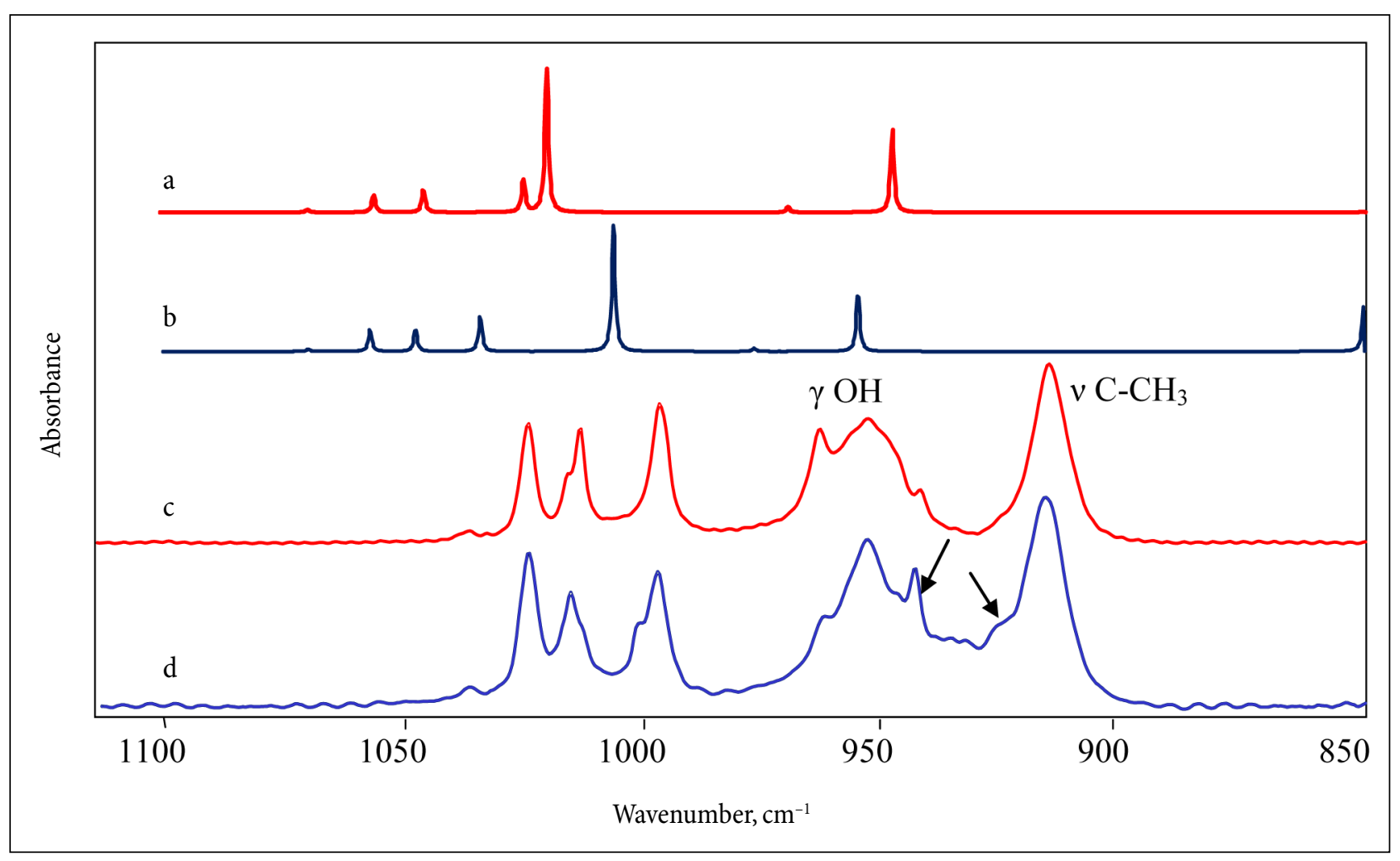

Fig. 9. (a) The calculated spectrum of acetylacetone; (b) the calculated spectra of acetylacetone-water complex; (c) the infrared absorption spectrum of acetylacetone in nitrogen (1:500) at $9 \mathrm{~K}$ temperature; (d) the infrared absorption spectrum of acetylacetone-water mixture in nitrogen (1:1:500) at $9 \mathrm{~K}$. Arrows denote acetylacetone bound to water bands

to identify bands appearing due to the complex formation. The band broadening in argon is a result of a much weaker interaction between the matrix and the molecule, therefore most of the internal dynamics of the AcAc molecule are preserved (a large amplitude $\mathrm{O}-\mathrm{H}$ stretch and $\mathrm{CH}_{3}$ torsion motions) thus making interpretation of the bands possible only after the approximate position is preliminarily known based on nitrogen matrix experiments.

The small band shifts of the AcAc molecule upon complex formation and remaining broad bands in the argon matrix confirm that water, hydrogen bonded to the AcAc molecule, has only a very small influence on the internal hydrogen bond strength in the AcAc molecule and does not have any significant influence on the internal dynamics of AcAc molecule atoms. In order to analyse the influence of electronic configuration of the molecule on the possibility of forming hydrogen bonds in detail, hexafluorinated acetylacetone molecule complexes with water were explored. The theoretical calculations predict different geometry and binding energy of the fluorinated AcAc-water complex. The binding energy of the hexafluoroacetylacetone-water complex is $11.5 \mathrm{~kJ} / \mathrm{mol}$, which is smaller than that of the acetylacetone-water complex by $12.1 \mathrm{~kJ} / \mathrm{mol}$. The list of the calculated and experimental vibrational bands is presented in Table 3. This is also reflected by the predicted water $\mathrm{O}-\mathrm{H}$ stretch bands position. The free $\mathrm{O}-\mathrm{H}$ stretch is predicted to be at the similar place as in the case of the acetylacetone-water complex (AcAc at $3885 \mathrm{~cm}^{-1}, 6 \mathrm{~F}-\mathrm{AcAc}$ at $3894 \mathrm{~cm}^{-1}$ ), but the change is strongly reflected in the bound to AcAc water $\mathrm{O}-\mathrm{H}$ stretch (AcAc at $3640 \mathrm{~cm}^{-1}, 6 \mathrm{~F}-\mathrm{AcAc}$ at $3778 \mathrm{~cm}^{-1}$ ). Experimentally we observe these bands for the $6 \mathrm{~F}$-AcAc-water complex isolated in argon at 3731 and $3580 \mathrm{~cm}^{-1}$ (Fig. 10). These bands are heavily perturbed by the water absorption and determination of the bound $\mathrm{O}-\mathrm{H}$ band position was possible only in the difference spectrum when the absorption bands of water dimers and trimers were removed. The weakness and broadness of the bands indicated that complex binding energy is smaller and much less localized for $6 \mathrm{~F}$-AcAc when compared to the AcAc-water complex. The spectral region between 1710 and $1580 \mathrm{~cm}^{-1}$ is very complicated for the samples isolated in the argon matrix. For pure 6F-AcAc we expect only two normal vibrations due to the $\mathrm{C}=\mathrm{O}$ and $\mathrm{C}=\mathrm{C}$ group stretch vibrations. In the experimental spectra we see two medium strength doublets. The same doublet structure is observed in nitrogen and even parahydrogen matrices [14] which points to the intrinsic dynamics in the 6F-AcAc molecule. The weak bands in between these two doublets are most likely combination bands. Addition of water complicates this region even more. It is possible to assign one band to the bending vibration of water bound to $6 \mathrm{~F}-\mathrm{AcAc}$ at $1589.5 \mathrm{~cm}^{-1}$. This band is always growing in intensity with increased water 
Table 3. The experimentally observed and calculated bands (in $\mathrm{cm}^{-1}$ ) of $6 \mathrm{~F}$-acetylacetone-water complex

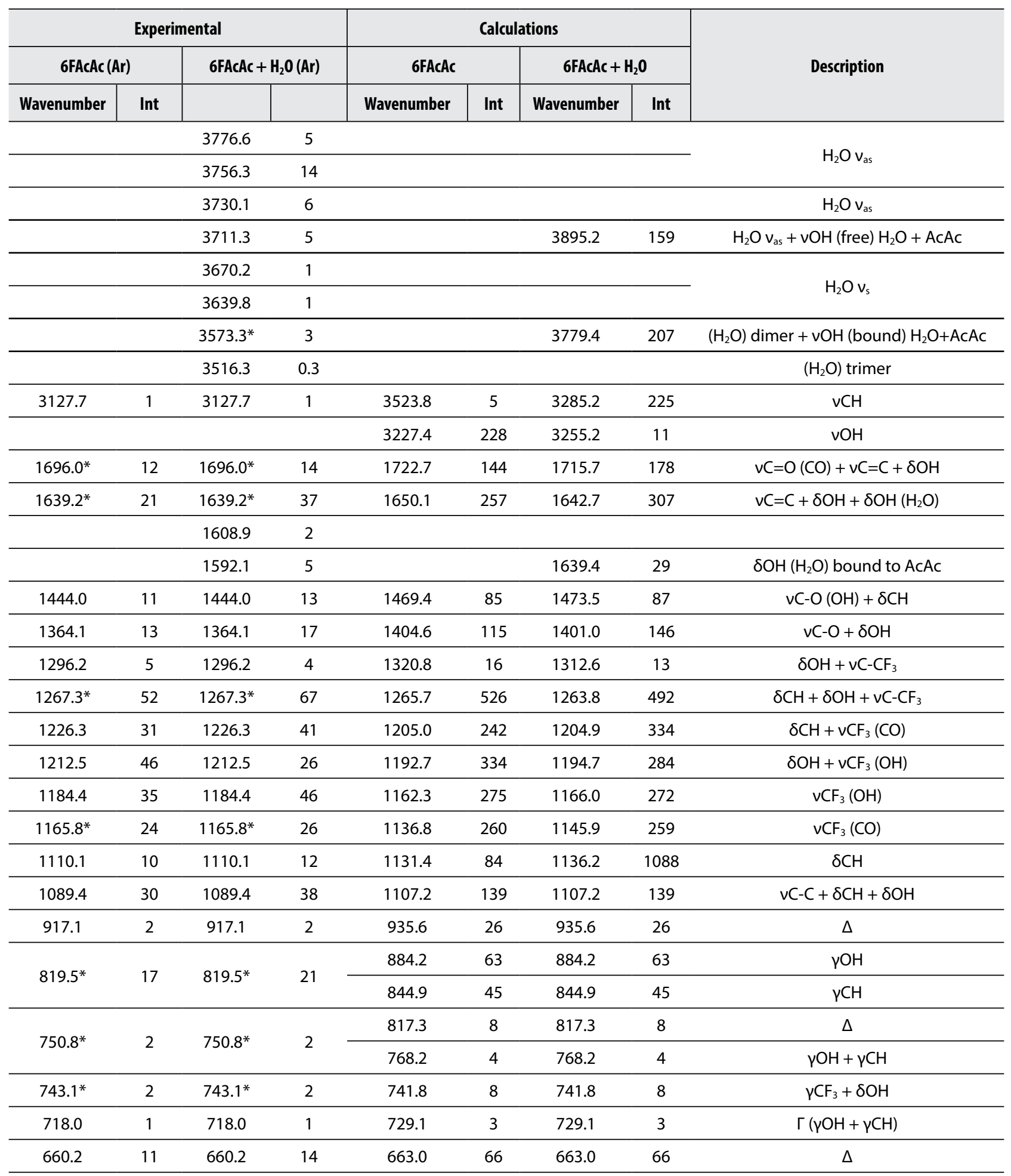

* Bands with splitting.

concentration. A complicated band structure does not allow a clear identification of the $\mathrm{C}=\mathrm{O}$ stretch band of $6 \mathrm{~F}-\mathrm{AcAc}$ bound to water. This fact also points out the weakness of the formed complex. The spectral region from 1300 to $900 \mathrm{~cm}^{-1}$ exhibits a few additional spectral bands appearing in the spectra of $6 \mathrm{~F}$-AcAc-water mixtures in argon (Fig. 11). The biggest difference between the spectra of the pure $6 \mathrm{~F}-\mathrm{AcAc}$ and the $6 \mathrm{~F}-\mathrm{AcAc}$-water mixture is the band at $1278 \mathrm{~cm}^{-1}$. Based on the calculations, it is attributed to a highly coupled vibrational transition consisting of $\mathrm{O}-\mathrm{H}$ in-plane deformation and $\mathrm{CF}_{3}$ stretch $(\mathrm{C}=\mathrm{O}$ side). The band position in the pure $6 \mathrm{~F}-\mathrm{AcAc}$ is at $1268 \mathrm{~cm}^{-1}$. It is interesting to note that the change of the $\mathrm{OH}$ in-plane deformation is not observed in the normal AcAc due to 


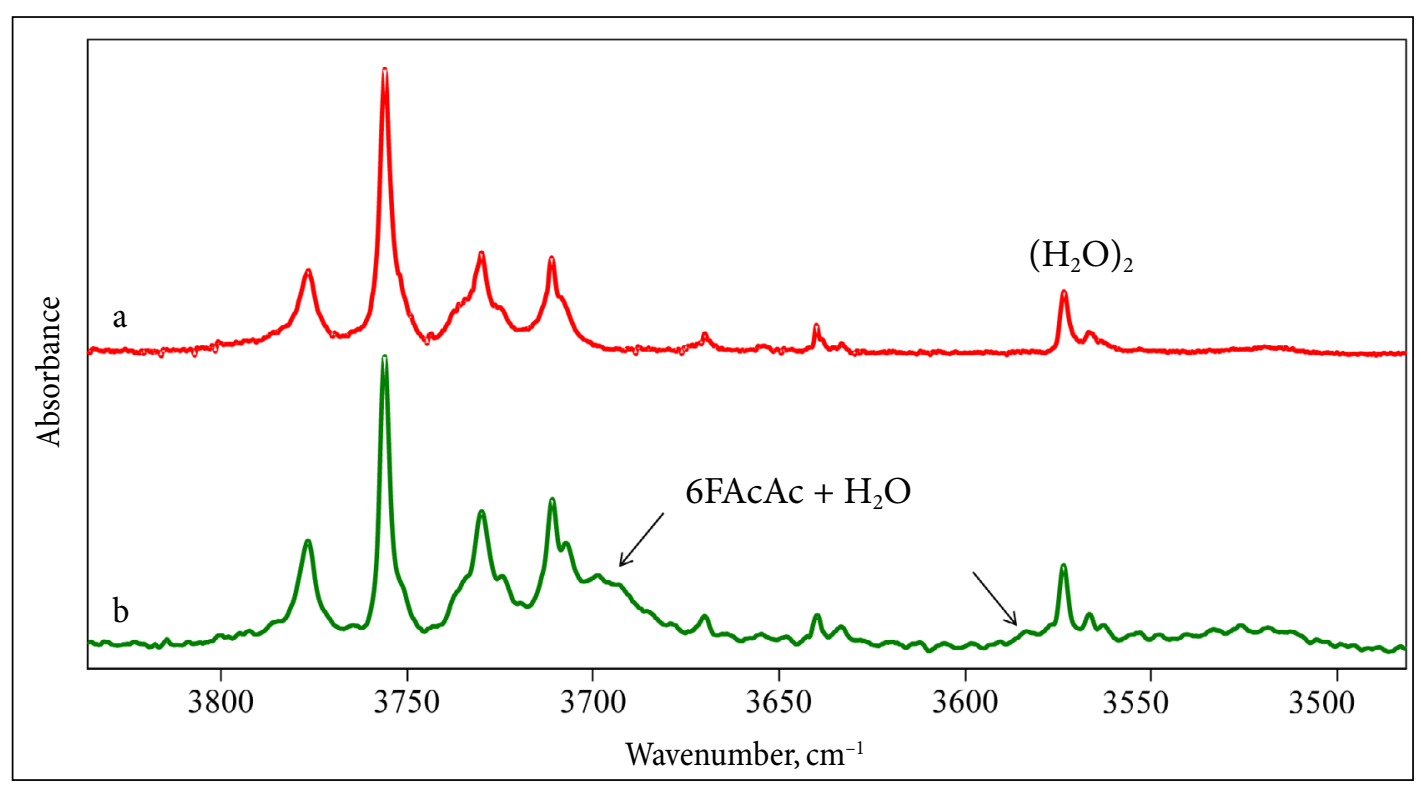

Fig. 10. (a) The infrared absorption spectrum of water in argon (1:500) at $9 \mathrm{~K}$ temperature; (b) the infrared absorption spectrum of hexafluoroacetylacetone-water mixture in argon (1:1:500) at $9 \mathrm{~K}$. Arrows denote bands attributed to water bound to hexafluoroacetylacetone

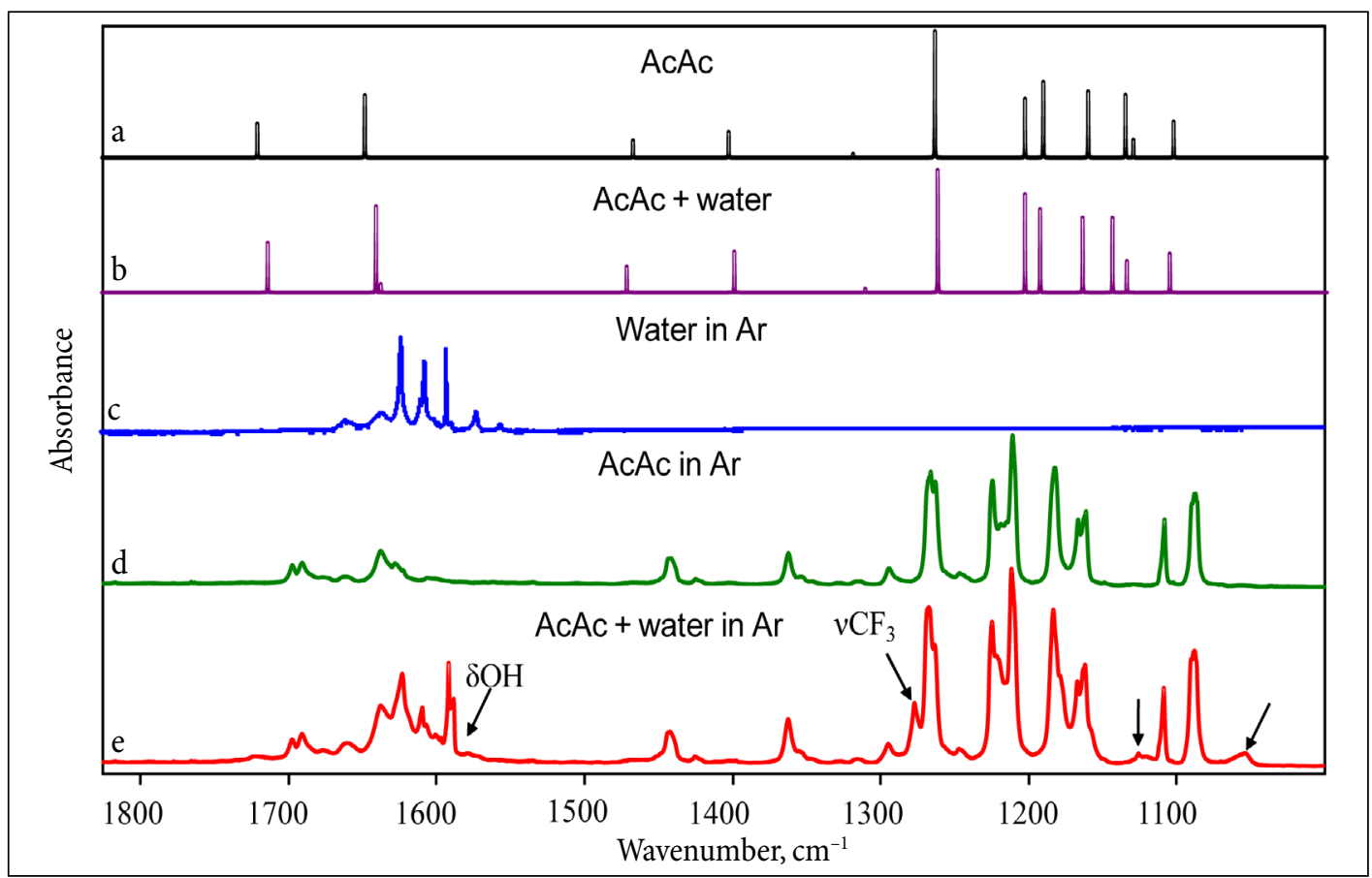

Fig. 11. (a) The calculated spectrum of hexafluoroacetylacetone; (b) the calculated spectra of hexafluoroacetylacetone-water complex; (c) the infrared absorption spectrum of water in argon (1:500) at $9 \mathrm{~K}$ temperature; (d) the infrared absorption spectrum of hexafluoroacetylacetone in argon (1:500) at $9 \mathrm{~K}$; (e) the infrared absorption spectrum of hexafluoroacetylacetone-water mixture in argon (1:1:500) at $9 \mathrm{~K}$. Arrows denote bands attributed to hexafluoroacetylacetone-water complex

a very broad band structure arising from the delocalization of hydrogen in the AcAc molecule. Two additional shoulder bands red shifted by $3 \mathrm{~cm}^{-1}$ from the bands in the pure $6 \mathrm{~F}$ AcAc are observed at 1264 and $1223 \mathrm{~cm}^{-1}$ and are mainly associated with the stretch vibrations of $\mathrm{CF}_{3}$ groups, which are highly coupled with the vibrations of $\mathrm{O}-\mathrm{H}$ and $\mathrm{C}=\mathrm{O}$ groups in the molecule. Two more weak bands appearing with an addition of water at 1126 and $1057 \mathrm{~cm}^{-1}$ are significantly shifted from the bands of pure 6F-AcAc. Based on the calculated spectra these two bands cannot be assigned to the normal vibrations of the 6F-AcAc-water complex and must be associated with combinational vibrations. 
The appearance of the new bands in the spectra of $6 \mathrm{~F}$ AcAc-water mixtures compared to the spectra of pure water and pure $6 \mathrm{~F}$-AcAc clearly signifies that the complex between $6 \mathrm{~F}-\mathrm{AcAc}$-water is formed. However, the small shifts and broadness of the bands indicates that the complex is much weaker than that of the normal AcAc-water. This is supported by theoretical calculations as well.

\section{CONCLUSIONS}

Theoretical calculations performed at the B3LYP $6-311++\mathrm{G}(3 \mathrm{df}, 3 \mathrm{pd})$ level and matrix isolation infrared absorption experiment results confirm that acetylacetone and water form hydrogen bonded complexes in argon and nitrogen. Only one complex with the most stable structure was observed experimentally for all the species. The spectral bands of the complex were identified and assigned to the normal vibrations of water and acetylacetone participating in the formation of the complex. The bond strength in the complex is similar to the bond strength in the water trimer - this is confirmed by the calculations and similar spectral shifts of the bound $\mathrm{O}-\mathrm{H}$ stretch observed in the water trimer and the acetylacetone-water complex. In spite of a moderate hydrogen bond strength only very small changes of the AcAc bands are observable. The observed fact that $\mathrm{O}-\mathrm{H}$ in the plane deformation band does not change upon formation of an external hydrogen bond with water suggests that water has a very minor influence on the strength and dynamics of an internal hydrogen bond in an AcAc molecule. The deuteration of water and acetylacetone $\mathrm{O}-\mathrm{H}$ and $\mathrm{C}-\mathrm{H}$ bonds results in a slight decrease of the complex hydrogen bond energy upon the deuteration. This is manifested in a smaller water molecule $\mathrm{O}-\mathrm{D}$ stretch shift from the monomer to the complex compared with the corresponding $\mathrm{O}-\mathrm{H}$ stretch shift. The fluorination of $\mathrm{CH}_{3}$ groups in acetylacetone results in a different complex geometry and a significant binding energy decrease manifested both in the DFT calculated energy and the observed smaller $\mathrm{OH}$ stretching shifts from the monomer to the complex.

\section{ACKNOWLEDGEMENTS}

This research was funded by a grant (No. TAP LZ-1/2015) from the Research Council of Lithuania.

The authors are grateful to "HCP Sauletekis" for the allocated computational time. Computations were performed on the resources at the High Performance Computing Center "HPC Sauletekis" in the Vilnius University Faculty of Physics.

\section{References}

1. G. C. Pimentel, A. L. McClellan, The Hydrogen Bond, W. H. Freeman, San Francisco (1960).

2. R. Parthasarathi, V. Subramanian, N. Sathyamurthy, J. Phys. Chem. A, 110, 3349 (2006).

3. T. Ishida, F. Hirata, S. Kato, J. Chem. Phys., 110, 11423 (1999).

4. N. V. Belova, V. V. Sliznev, H. Oberhammer, G. V. Girichev, J. Mol. Struct., 978, 282 (2010).

5. G. W. Mines, H. Thompson, Proc. Royal Soc. A, 342, 327 (1975).

6. A. Trivella, P. Roubin, P. Theule, M. Rajzmann, S. Coussan, C. Manca, J. Phys. Chem. A, 111, 3074 (2007).

7. A. Trivella, T. N. Wassermann, J. M. Mestdagh, et al., Phys. Chem. Chem. Phys., 12, 8300 (2010).

8. N. Nagashima, S. Kudoh, M. Takayanagi, M. Nakata, J. Phys. Chem. A, 105, 10832 (2001).

9. S. F. Tayyari, F. Milani-nejad, Spectrochim. Acta, Part A, 56, 2679 (2000).

10. R. R. Lozada-Garcia, J. Ceponkus, W. Chin, M. Chevalier, C. Crépin, Chem. Phys. Lett., 504, 142 (2011).

11. R. R. Lozada-Garcia, J. Ceponkus, M. Chevalier, W. Chin, J. M. Mestdagh, C. Crépin, Angew. Chem., Int. Ed., 51, 6947 (2012).

12. M. Van Thiel, E. D. Becker, G. C. Pimentel, J. Chem. Phys., 27, 486 (1957).

13. M. Takano, T. Takahashi, K. Iijima, Y. Yamada, J. Mol. Spectrosc., 333, 27 (2017).

14. A. Gutiérrez Quintanilla, Ph. D. Thesis, Univeriste ParisSaclay, Orsay (2016).

15. A. D. Becke, J. Chem. Phys., 104, 1040 (1996).

16. M. J. Frisch, G. W. Trucks, H. B. Schlegel, et al., Gaussian 03, Revision E. 01, Gaussian Inc., Wallingford CT (2004).

17. R. M. Bentwood, A. J. Barnes, W. J. Orville-Thomas, J. Mol. Struct., 84, 391 (1980).

18. J. Ceponkus, A. Engdahl, P. Uvdal, B. Nelander, Chem. Phys. Lett., 581, 1 (2013).

19. J. Ceponkus, B. Nelander, J. Phys. Chem. A, 108, 6499 (2004).

20. J. Ceponkus, P. Uvdal, B. Nelander, J. Chem. Phys., 138(24), 244305 (2013).

21. X-Z. Li, B. Walker, A. Michaelides, Proc. Natl. Acad. Sci. U. S. A., 108(16), 6369 (2011).

22. J. Čeponkus, D. Leščiūte, D. Čepulinskaitè, M. Pučetaitė, V. Šablinskas, Lith. J. Phys., 49(1), 53 (2009).

23. J. Andersen, J. Heimdal, R. W. Larsen, J. Chem. Phys., 143(22), 224315 (2015). 
Justinas Čeponkus, Rasa Platakytė, Valdas Šablinskas, Alejandro Gutierrez Quintanilla

\section{ACETILACETONO, D2-ACETILACETONO IR HEKSAFLUOROACETILACETONO-VANDENS MOLEKULIŲ KOMPLEKSŲ ARGONO IR AZOTO MATRICOSE TYRIMAS FTIR SPEKTRINIU METODU}

Santrauka

Vandenilinis ryšys nepaprastai svarbus daugelyje sričių, jis keičia medžiagos savybes ir daro ịtaką îvairiems procesams, vykstantiems biologinèse ir cheminèse sistemose. Toks ryšys gali formuotis tiek tarp elektroneigiamų atomų ar grupių turinčių molekulių, tiek jų viduje. Acetilacetonas - diketonų tipo molekulè, kurios enolinè forma stabilizuojama stipriu vidiniu vandeniliniu ryšiu. Vandens poveikis vidinio vandenilinio ryšio struktūrai ir dinamikai yra gera modelinè sistema norint suprasti sudètingus makromolekulèse vykstančius procesus.

Šiame darbe tirti acetilacetono ir vandens kompleksai naudojant žemų temperatūrų matricinę izoliaciją ir infraraudonosios sugerties spektroskopiją. Taip pat eksperimentai buvo vykdomi su deuteruotomis medžiagomis bei heksafluoroacetilacetonu ir vandeniu, norint geriau suprasti molekulès struktūros ir vandenilinio ryšio abipusę įtaką. Matricinè izoliacija, derinama su infraraudonosios sugerties spektroskopija, yra vienas tinkamiausių metodų tokioms molekulèms ir jų kompleksams tirti. Silpni asociatai sta- bilizuojami inertinejje matricoje, o keičiant bandinio koncentraciją galima kontroliuoti ir stebèti spektrinių juostų atsiradimą bei augimą.

Užregistravus acetilacetono ir vandens mišinių spektrus bei palyginus juos su grynųjų medžiagų spektrais, naujos išaugusios spektrinès juostos priskirtos vandeniliniu ryšiu surištiems kompleksams. Visų juostų priskyrimas atitinkamiems virpesiams atliktas remiantis bandinio atšildymo eksperimentu bei tankio funkcionalo (DFT) B3LYP 6-311++G(3df, 3pd) metodo skaičiavimais. Acetilacetono ir vandens kompleksu juostos pozicija nurodo vidutinio stiprumo vandenilinị ryšĭ, panašų ị stebimą vandens trimeruose. Eksperimentai parodè, kad vandenilinio ryšio susiformavimo ittaka acetilacetono molekulès struktūrai ir dinamikai yra minimali. Panašias išvadas galima padaryti ir apie deuteruoto acetilacetono bei $\mathrm{D}_{2} \mathrm{O}$ molekulinius asociatus. Jų kompleksų susidarymo energija yra identiška acetilacetono-vandens sistemai $(23,5 \mathrm{~kJ} / \mathrm{mol})$. Deuteruoto vandens surištos OD grupès virpesio juosta yra pasislinkusi nuo monomeru juostos tiek pat, kiek ir $\mathrm{OH}$ grupés virpesio acetila-

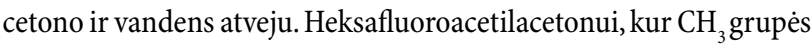
pakeičiamos $\mathrm{CF}_{3}$, suskaičiuota kompleksų energija yra dvigubai mažesnè $(11,5 \mathrm{~kJ} / \mathrm{mol})$. Tarpmolekulinio vandenilinio ryšio susilpnèjimą patvirtina ir daug mažesnis $\mathrm{OH}$ valentinio virpesio poslinkis eksperimentiniuose spektruose. Galima daryti išvadą, kad molekulinių grupių, net esančių toli nuo vandenilinio ryšio akceptoriaus, elektroninè struktūra turi ịtakos ryšio formavimuisi. 
